International Journal of Business Management and Economic Review

Vol. 4, No. 06; 2021

ISSN: 2581-4664

\title{
THE MEDIATING EFFECT OF AUTHENTIC LEADERSHIP OF SCHOOL HEADS ON THE RELATIONSHIP BETWEEN TEAMWORK ATTITUDES AND WORK ENGAGEMENT
}

\author{
Eugenio S. Guhao Jr. and Lyndon A. Quines \\ Khristine Marie D. Concepcion,Eufrosina P. Mines ,University of Mindanao Professional Schools Matina, Davao \\ City, Philippines
}

http://doi.org/10.35409/IJBMER.2021.3342

\begin{abstract}
This study was aimed at research the mediating effect of authentic leadership of on the relationship between teamwork attitudes and work engagement among 357school heads in Davao Region, Philippines. This study employed non-experimental design utilizing descriptive correlation technique. The statistical tools used were mean, Pearson-r and regression technique. Research instruments on authentic leadership, teamwork attitudes and work engagement which were pilot tested and content validated were used as sources of data. Using Pearson-r, the results revealed significant relationships between authentic leadership, teamwork attitudes and work engagement of school heads. Utilizing path analysis, the results of the study revealed partial mediating effect of authentic leadership on the relationship between teamwork attitude and work engagement. This means that the mediating role played by the honest leadership of the school heads partly helped to explain the mechanism that was responsible for the relationship between the attitude of cooperation and the dedication to work.
\end{abstract}

Keyword: Educational Management; Mediating Effect; Authentic Leadership of School Heads; Teamwork Attitude; Work Engagement; Philippines.

\section{INTRODUCTION}

Work Engagement is not productivity or an output - using an analogy, engagement may be smoke but it is not fire. The primary concern of leaders is increasing productivity, output, or innovation. Unfortunately, employee work engagement, employee satisfaction, emotional intelligence, etc. may contribute to productivity, but they are not productivity. An employee may be fully engaged and emotionally tied to the firm but without the proper training, leaders, resources, etc. no amount of commitment will improve their outputs. Emotional states are hard to understand and measure, while behaviours and productivity are not. A superior approach is one that looks broadly at all of the factors that increase productivity, that lower labor costs, and that increase the value of labor outputs and innovation (Verma, 2015).

However, work-engagement should be seen as independent factors instead of opposite poles. Moreover, work-engagement as a positive affective-cognitive state, characterized by vigor, dedication and absorption. The definition consists of three dimensions: vigor, commitment and absorption. Vigor is characterized by high energy levels, emotional endurance and ability to put effort into one's work and perseverance even when workers face difficulties. Dedication refers to 


\section{International Journal of Business Management and Economic Review}

Vol. 4, No. 06; 2021

ISSN: 2581-4664

a deep dedication to work that is considered to be useful and important, encouraging and demanding, and evokes pride and excitement feelings. Absorption is characterized by a nice way of focusing entirely on and being consumed deeply by the work. When workers are overwhelmed by their job they find the time passes quickly and it's hard to separate them from the job (GonzálezRoma, Schaufeli, Bakker, Lloret, 2006; Schaufeli, \& Bakker, 2004).

Theoretically, job participation with organizations is correlated with all kinds of positive outcomes. Engaged staff are full of enthusiasm, dedicated to the organization, and work hard without complaining about job-related stress. Engaged workers are not only successful in this way, but their positive approach to the job also creates a positive environment at job. There are some signs that this positive environment is also having a positive impact on others at work. Engaged employees are happy with their employment and are less likely to abandon their jobs (Roozeboom\&Schelvis, 2016).

Cognizant of the importance of studies on work engagement, the researcher made an extensive review of literature for possible variables associated with it. Teamwork attitude was the first variable considered to be relevant. It plays an important factor in the work engagement as it maximizes the individual strengths of team members to bring out their best. It istherefore a necessity that leaders facilitate and build the teamwork skills of their people ifthey are to steer a companytoward success (Yukelson, 2017).

Another variable that caught the attention of the researcher is authentic leadership. It means that authentic leaders begin with the will and commitment within to work on themselves (Michie\& Gooty,2005).

However, the researcher would like to know how authentic leadership mediate the effect of teamwork attitudes and work engagement.It is on the above context that the researcher took interest to examine if authentic leadership will mediate the relationship between teamwork attitudes and work engagement; hence, making this study a generation of new knowledge that can give specific contribution to the field of education.

\subsection{Research Questions:}

The main thrust of this study was to find out the mediating effect of authentic leadership on the relationship between teamwork attitudes and work engagement of public elementary schools in Davao Region.

Specifically, the following objectives were formulated:

1. To describe the level of teamwork attitudes of school heads in terms of: team structure, leadership, situation monitoring, mutual support and communication;

2. To ascertain the level of work engagement of public elementary schools in terms of: vigor, dedication and absorption;

3. To measure the level of authentic leadership of school heads;

4. To determine the significance of the relationship between: teamwork attitudes and work engagement; teamwork attitude and authentic leadership; and authentic leadership and work engagement; and

5. To determine the significance of mediation of authentic leadership on the relationship between teamwork attitudes and work engagement. 
International Journal of Business Management and Economic Review

Vol. 4, No. 06; 2021

ISSN: 2581-4664

\subsection{Theoretical Framework}

This study isanchored on the theory of Authentic Leadership by Avolio, Gardner, Walumbwa, Luthans\& May (2004) that authentic leaders as those who are genuinely conscious of how they think and act and viewed by others as being mindful of the values / moral viewpoints, experience, and talents of their own and others; conscious of the sense in which they operate; and who are positive, ambitious, optimistic, resilient, and of a strong moral nature. (Avolio\& Gardner, 2005).Luthans and Avolio (2009) demarcate the related concept of authentic leadership in organizations as a mechanism that draws from both positive psychological capacities and a highly established organizational background, resulting in greater self-awareness and positive selfregulated actions on the part of leaders and associates, promoting positive self-development.

On the other hand, work involvement can be characterized as a state of vigour, commitment and absorption. Work and personal resources are the key predictors of commitment; these resources are increasing their salience in the context of high demands on jobs. The workforce are more imaginative, more successful and more willing to go the extra mile(Bakker \&Demerouti, 2008).

Moreover, the collectivist orientation may promote such critical aspects of teamwork as shared intent, interdependence of tasks and group emphasis. In this collectivist culture, the value of partnerships will also undermine individual interests for the benefit of working groups (teams). Moreover, culture has deep vertical relationships of filial piety, paternalism and hierarchy and deep demands for conformity, facial grooming and social regulation (Aycan 2006). If teams were established by managerial authority and had strong appointed members, these vertical relationships would encourage teamwork. But conventional principles will make teamwork easier.

\subsection{Conceptual Framework}

Figure 1 presents the conceptual framework showing the variables of the study. The independent variable of this research focuses on the Teamwork Attitudes which is depicted by the indicators namely: team structure, leadership, situation monitoring, mutual support and communication (Brock, Abu-Rish, Chiu, Hammer, Wilson, Vorvick\& Zierler,2013).

The dependent variable of the study is Work Engagement which is measured in terms of vigor, dedication and absorption (Bakker\& Demerouti, 2008). The mediating variable is Authentic Leadership. This refers to displaying the attributes and characteristics of becoming a more genuine leader, and its followers will react positively and support the organization. George defines five dimensions, each associated with an observable characteristic: intention and passion, beliefs and behaviour, relationships and connectedness, self-discipline and integrity, and heart and compassion (Penn State, 2017).

A mediating variable is one that lies between causal factors and an end result. It further aims to estimate the way a variable affects the impact of $\mathrm{X}$ on Y.A mediator is supposed to be responsible for the result and not vice versa. One justification for mediation research is to try to understand the process by which the initial variable influences the outcome(Baron \& Kenny, 1986). Authentic Leadership may function as a mediator when variations in the perceived teamwork attitudes of school heads and work engagement for the variations in authentic leadership; variations in 


\section{International Journal of Business Management and Economic Review}

Vol. 4, No. 06; 2021

ISSN: 2581-4664

authentic leadership significantly account for the variations in work engagement and the direct link between teamwork attitude and that of work engagement are no longer significant.

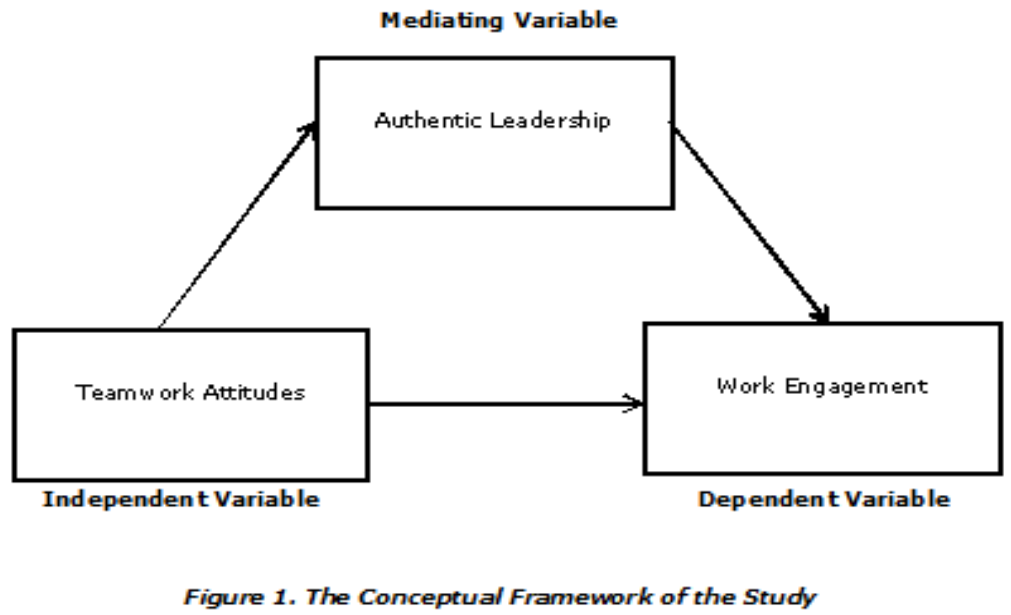

Furthermore, a variable may act as a full mediator if it meets the following conditions: variations in the level of the independent variable account significantly for variations in the presumed mediator; dependent variable differences in the mediator largely account for; and when both the independent variable and the mediating variable appear in the model, an already important relationship between the independent and dependent variables is no longer relevant and the direct path is zero (Baron \& Kenny, 1986).

\section{METHOD}

This study used non-experimental quantitative design using the analysis descriptive correlation technique designed to collect study-related data, ideas, facts and details. Researchers collect data in non-experimental research without changing or introducing treatments (Gehle, 2013). In this study the variables were not manipulated and the setting was not controlled. Descriptivecorrelation study architecture explains and interprets what is, shows current and non-existent conditions and relationships. Further it is a fact finding study that allowed the researcher to examine characteristics, behaviors, and experiences of study participants (Calderon, 2006; PalerCalmorin\&Calmorin, 2007).

The study is descriptive in nature since it assessed the levels of teamwork attitudes and authentic leadership of school heads, and work engagement of public elementary schools in Region XI.This is correlational since it investigated the relationship between variables such as teamwork attitude, work engagement and authentic leadership, with the use of the survey questionnaire as a tool in gathering the primary data. The interest of the study is to investigate the relationship between teamwork attitude and work engagement; the relationship between teamwork attitude and authentic leadership; the relationship between authentic leadership and work engagement; and the mediating effect of authentic leadership on the relationship between teamwork attitude and work engagement of public elementary schools heads in Davao Region. Path Analysis was employed in determining the mediation. 


\section{International Journal of Business Management and Economic Review}

Vol. 4, No. 06; 2021

ISSN: 2581-4664

A total of 357 school heads of the Department of Education Region XI as participants of the study were selected randomly.

Survey questionnaires were administered with the approval of the Regional Director. Furthermore, the study adapted a purposive sampling technique, a non-probability sampling approach that is decided based on total traits of population (Crossman, 2018).

To ensure confidentiality, the questionnaires did not require the respondents to write their names and other personal information covered under Philippine Data Privacy Act.

There are three sets of questionnaires adapted from different authors, which were validated by experts on questionnaire construction. The adapted standardized questionnaire is valid in contents for they were already tested and proven by the author as it underwent modification to classify the questions. The questionnaire was designed in a very comprehensive form with the help of the expert validators to provide the respondents with ease and comfort in answering each question and in understanding the objective of the study.The first part of the questionnaire deals with teamwork attitude of school heads with indicators such as team structure, leadership, situation monitoring mutual support and communication.

The instrument adapted and modified was taken from the study of Brock, Abu-Rish, Chiu, Hammer, Wilson, Vorvick\&Zierler (2013).The second set of instrument employed is to measure work engagement. The instrument was adapted and modified from the study of Bakker and Demerouti (2008). The third set of the questionnaire was adapted and modified from the study of Avolio, Gardner, and Walumbwa (2004). The five-point Likert scale was used for the research variables. According to Santos (2007), in response to a large number of things concerning an attitude, object and stimulus, Likert Scale allows individuals to tick on a box / blank. The number obtained from a rating scale is usually viewed directly as measurements by measuring averages or, more generally, any numerical operation.

The five orderable gradations of teamwork attitudes with their respective range of means and descriptions are as follows:

\begin{tabular}{|c|c|c|}
\hline Range of Means & Descriptive Level & Interp retation \\
\hline $4.20-5.00$ & Very Hgh & $\begin{array}{l}\text { This means that teamwork attitudes } \\
\text { are manifested at all times. }\end{array}$ \\
\hline $3.40-4.19$ & $\mathrm{High}$ & $\begin{array}{l}\text { This means that teamwork attitudes } \\
\text { are manifested most of the time. }\end{array}$ \\
\hline $2.30-3.39$ & Moderate & $\begin{array}{l}\text { This means that teamwork attituces } \\
\text { are manifested occasionally. }\end{array}$ \\
\hline $1.80-2.59$ & Low & $\begin{array}{l}\text { This means that teamwork attitudes } \\
\text { are manifested in few instances. }\end{array}$ \\
\hline $1.00-1.79$ & Very Low & $\begin{array}{l}\text { This means that teamwork attitudes } \\
\text { are not manifested at all. }\end{array}$ \\
\hline
\end{tabular}

In evaluating the level of Work Engagement, the following scale was used. 
International Journal of Business Management and Economic Review

Vol. 4, No. 06; 2021

ISSN: 2581-4664

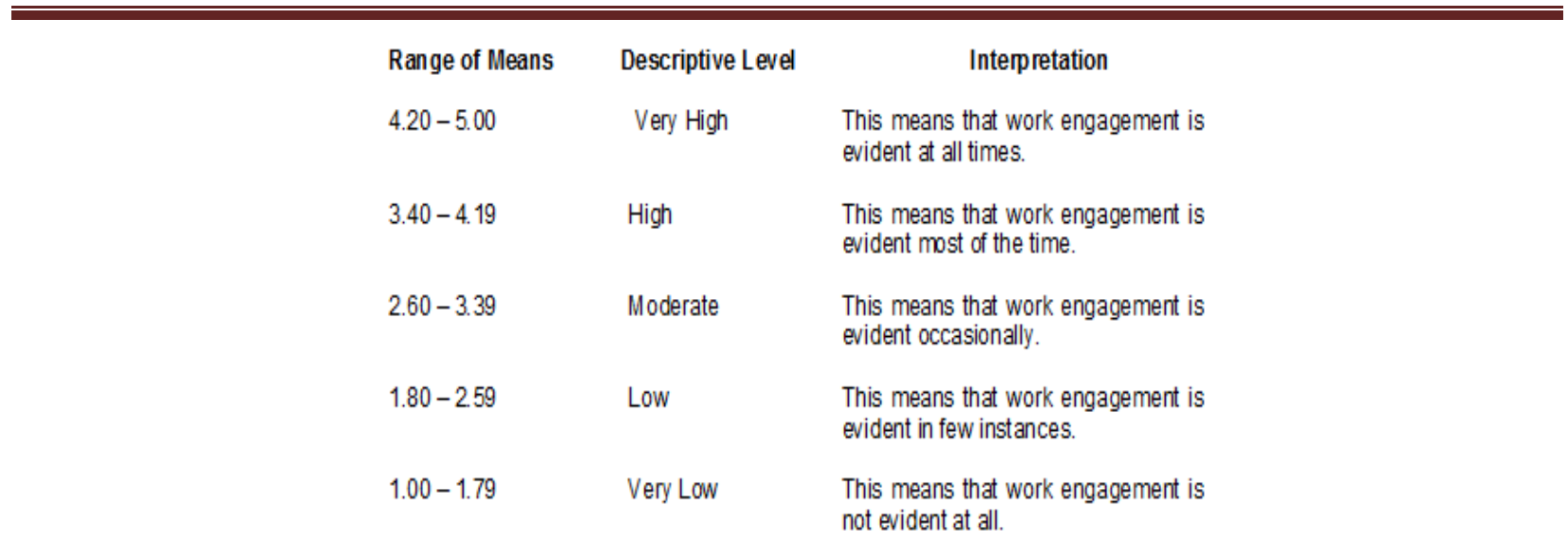

In determining the level of authentic leadership, the means were interpreted using the scale below.

\begin{tabular}{|c|c|c|}
\hline Range of Means & Descriptive Level & Interp retation \\
\hline $4.20-5.00$ & Very High & $\begin{array}{l}\text { This means that authentic leadership } \\
\text { is manifested or felt at all times. }\end{array}$ \\
\hline $3.40-4.19$ & High & $\begin{array}{l}\text { This means that authentic leadership } \\
\text { is manifested or felt most of the time. }\end{array}$ \\
\hline $2.60-3.39$ & Moderate & $\begin{array}{l}\text { This means that authentic leadership } \\
\text { is manifested or felt occasionally. }\end{array}$ \\
\hline $1.80-2.59$ & Low & $\begin{array}{l}\text { This means that authentic leadership } \\
\text { is manifested or felt on few } \\
\text { occasions. }\end{array}$ \\
\hline $1.00-1.79$ & Very Low & $\begin{array}{l}\text { This means that authentic leadership } \\
\text { is not manifested or felt at all. }\end{array}$ \\
\hline
\end{tabular}

For more comprehensive interpretation and analysis of the data, the following statistical tools were utilized.Mean was used to determine the level of teamwork attitude of school heads, level of authentic leadership and level of work engagement to answer problems 1,2 and 3. Pearson-rwas utilized to determine if the relationship between teamwork attitude of school heads and work engagement is really significant.Path Analysis was employed to prove the mediation and to strengthen the obtained result.

\section{RESULTS AND DISCUSSION}

\subsection{Level of Teamwork Attitudes of School Heads}

Shown in Table 1 is the level of Teamwork Attitudes of School Heads. The standard deviation was less than 1.00 which indicated consistency of responses. The overall mean score was 4.31 labeled as very high. Distinctively, the level of Teamwork Attitude of school heads on the following indicators were as follows: team structure has a mean of 4.35 described as very high, leadership has a mean of 4.49 with a descriptive level of very high, situation monitoring has a 
mean of 4.32 characterized as very high, mutual support has a mean of 4.23 labeled as very high and communication has a mean of 4.15 with a descriptive level of high.

The very high level of teamwork attitude is associated from the study of Ruiz Ulloa and Adams, 2004) that when mature communication, responsible interdependence, psychological health, shared intent, clarity of task and clear goal are present during the teaming process, the experience can have a positive impact on the attitude of the person towards teamwork.

\section{Table 1. Level of Teamwork Attitudes of School Heads}

\begin{tabular}{|cccc|}
\hline Items & SD & Mean & DE \\
Team Structure & 0.689 & 4.35 & Very High \\
Leadership & 0.689 & 4.49 & Very High \\
Situation & 0.732 & 4.32 & Very High \\
Monitoring & & & \\
Mutual Support & 0.721 & 4.23 & Very High \\
Communication & 0.731 & 4.15 & High \\
Overall & $\mathbf{0 . 6 6 2}$ & $\mathbf{4 . 3 1}$ & Very High \\
\hline
\end{tabular}

\subsection{Level of Work Engagement}

Shown in Table 2 is the Level of Work Engagement of school head in public elementary schools in Davao Region. The overall mean score was 4.17 labeled as high. Particularly, the level of work engagement on the following indicators were as follows: vigor has a mean of 4.09 with an interpretation of high, dedication has a mean of 4.41 labeled as very high and absorptionhas a mean of 4.01 characterized as high.

The high level of work engagement correlates the result based from the study of Roozeboom and Schelvis (2016) that the employees involved are full of energy, dedicated to the company and work hard without reports of job-related stress. Engaged workers are not only successful in this way, but their positive approach to the job also creates a positive environment at job.There are some signs that this positive environment is also having a positive impact on others at work. Committed employees are content with their work and are less likely to abandon their employers.

Table 2. Level of Work Engagement

\begin{tabular}{|cccc|}
\hline Items & SD & Mean & DE \\
Vigor & 0.684 & 4.09 & High \\
Dedication & 0.715 & 4.41 & Very High \\
Absorption & 0.759 & 4.01 & High \\
Overall & $\mathbf{0 . 6 6 6}$ & $\mathbf{4 . 1 7}$ & High \\
\hline
\end{tabular}

\subsection{Level of Authentic Leadership}

Shown in Table 3 is the Level of Authentic Leadership of school heads in Davao Region. The overall mean score was 4.09 described as high. This implies that the authentic leadership is manifested or felt most of the time. 
The high level of authentic leadershiplinked from Avolio\& Gardner (2005) that a leader may gain credibility and create trust by cultivating honest followership. Authentic leaders show self-awareness by focusing on their own strengths, shortcomings and beliefs. Truly, honest leaders know their talents and respect them, and accept their weaknesses. When honest leaders demonstrate emotional openness, they express their own thoughts and opinions freely, and do not reveal their feelings inappropriately to followers; they maintain a good balance. Moreover, authentic leaders are balanced in their approach, seeking opinions from subordinates and welcoming opposing viewpoints and fairly considering the value of those viewpoints. Authentic leaders often possess a clear moral code they display in their relationships and decision-making; this ethical structure is immune to outside influences.

Table 3. Level of Authentic Leadership

\begin{tabular}{|cccc|}
\hline Items & SD & Mean & DE \\
$\begin{array}{c}\text { Self-Awareness } \\
\text { Internalized Moral } \\
\text { Perspective } \\
\text { Balanced }\end{array}$ & 0.726 & 4.22 & $\begin{array}{c}\text { Very High } \\
\text { High }\end{array}$ \\
$\begin{array}{c}\text { Processing } \\
\text { Relational } \\
\text { Transparency } \\
\text { Overall }\end{array}$ & 0.814 & 4.12 & High \\
\hline
\end{tabular}

\subsection{Significance on the Relationship between Levels of Teamwork Attitudes and Authentic Leadership}

Displayed in Table 4 were the results of the test of relationship between teamwork attitude and authentic leadership. Reflected in the hypothesis, the relationship was tested at 0.05 level of significance. The overall $\mathrm{r}$-value of .872 with a $\mathrm{p}$-value of $<0.01$ signified the rejection of the null hypothesis. It means that there is a significant relationship between teamwork attitude and authentic leadership. This implies that the school heads' teamwork attitude is correlated with authentic leadership.

The result is associated with the study of Lyubovnikova, Legood, Turner\&Mamakouka, (2017) that authentic leadership will predict a particular reflexivity regulatory team phase, which will in turn be linked to two outcomes of team success, effectiveness and productivity. Moreover, authentic leadership served to shape team actions collectively, manifesting reflexivity in the team process, which in effect positively predicted team success. We conclude with a review about how this research expands honest leadership theoretical understanding of teamwork and delineates some practical consequences for leaders and organizations. 
International Journal of Business Management and Economic Review

Vol. 4, No. 06; 2021

ISSN: 2581-4664

Table. 4 Significance on the Rela tionship between Levels of Tearmwork Attitudes and Authentic Leadership

\begin{tabular}{|c|c|c|c|c|c|}
\hline \multirow[b]{2}{*}{$\begin{array}{l}\text { Tearnwork } \\
\text { Attitudes }\end{array}$} & \multicolumn{4}{|c|}{ Authentic Leadership } & \multirow[b]{2}{*}{$\begin{array}{c}\text { Overall } \\
\text { Authentic } \\
\text { Leadership }\end{array}$} \\
\hline & $\begin{array}{c}\text { Self- } \\
\text { Awareness }\end{array}$ & $\begin{array}{c}\text { Internalized } \\
\text { Moral } \\
\text { Perspective }\end{array}$ & $\begin{array}{c}\text { Balanced } \\
\text { Processing }\end{array}$ & $\begin{array}{c}\text { Relational } \\
\text { Transparency }\end{array}$ & \\
\hline Team Structure & $\begin{array}{l}0.751^{*} \\
(0.000)\end{array}$ & $\begin{array}{l}0.720^{*} \\
(0.000)\end{array}$ & $\begin{array}{l}0.712^{*} \\
(0.0000\end{array}$ & $\begin{array}{l}0.591^{*} \\
(0.000)\end{array}$ & $\begin{array}{l}0.782^{*} \\
(0.000)\end{array}$ \\
\hline Leadership & $\begin{array}{l}0.739^{*} \\
(0.000)\end{array}$ & $\begin{array}{l}0.742^{*} \\
(0.000)\end{array}$ & $\begin{array}{l}0.686^{*} \\
(0.000)\end{array}$ & $\begin{array}{l}0.600^{*} \\
(0.000)\end{array}$ & $\begin{array}{l}0.780^{*} \\
(0.000)\end{array}$ \\
\hline $\begin{array}{l}\text { Situation } \\
\text { Monitoring }\end{array}$ & $\begin{array}{l}0.758^{*} \\
(0.000)\end{array}$ & $\begin{array}{l}0.761^{*} \\
(0.000)\end{array}$ & $\begin{array}{l}0.774^{*} \\
(0.000)\end{array}$ & $\begin{array}{l}0.626^{*} \\
(0.000)\end{array}$ & $\begin{array}{l}0.824^{*} \\
(0.000)\end{array}$ \\
\hline Mutual Support & $\begin{array}{l}0.767^{*} \\
(0.000)\end{array}$ & $\begin{array}{l}0.786^{*} \\
(0.000)\end{array}$ & $\begin{array}{l}0.762^{*} \\
(0.000)\end{array}$ & $\begin{array}{l}0.616^{*} \\
(0.000)\end{array}$ & $\begin{array}{l}0.826^{*} \\
(0.000)\end{array}$ \\
\hline Communication & $\begin{array}{l}0.724^{*} \\
(0.000)\end{array}$ & $\begin{array}{l}0.813^{*} \\
(0.000)\end{array}$ & $\begin{array}{l}0.790^{*} \\
(0.000)\end{array}$ & $\begin{array}{l}0.646^{*} \\
(0.000)\end{array}$ & $\begin{array}{l}0.839^{*} \\
(0.000)\end{array}$ \\
\hline $\begin{array}{l}\text { Overall } \\
\text { Teamwork } \\
\text { Attitudes }\end{array}$ & $\begin{array}{l}0.805^{*} \\
(0.000)\end{array}$ & $\begin{array}{l}0.824^{*} \\
(0.000)\end{array}$ & $\begin{array}{l}0.803^{*} \\
(0.000)\end{array}$ & $\begin{array}{l}0.663^{*} \\
(0.000)\end{array}$ & $\begin{array}{l}0.872^{*} \\
(0.000)\end{array}$ \\
\hline
\end{tabular}

-Significant at 0.05 significance level.

\subsection{Significance on the Relationship between Levels of Authentic Leadership and Work Engagement}

Displayed in Table 5 were the results of the test of relationship between authentic leadership and work engagement. Reflected in the hypothesis, the relationship was tested at 0.05 level of significance. The overall $r$-value of .854 with a $p$-value of $<0.01$ signified the rejection of the null hypothesis. It means that there is a significant relationship between authentic leadership andwork engagement. This implies that the school heads' authentic leadership is correlated with work engagement.

The results corroborates the study of Hassan\& Ahmed (2011) that authentic leaders show a high degree of honesty, have a strong sense of mission and are committed to the core values they hold. As a result, in their workgroups they foster a more trusting relationship which translates into many positive results. The present study explored how authentic leadership contributes to the trust in leadership of subordinates and how this faith, in effect, predicts the commitment of subordinates to the job. Results suggested that authentic leadership fostered the confidence of subordinates in the leader, and contributed to the dedication to work. Interpersonal trust also predicted the work engagement of employees, as well as mediated the relationship between this leadership style and the work engagement of employees. 
International Journal of Business Management and Economic Review

Vol. 4, No. 06; 2021

ISSN: 2581-4664

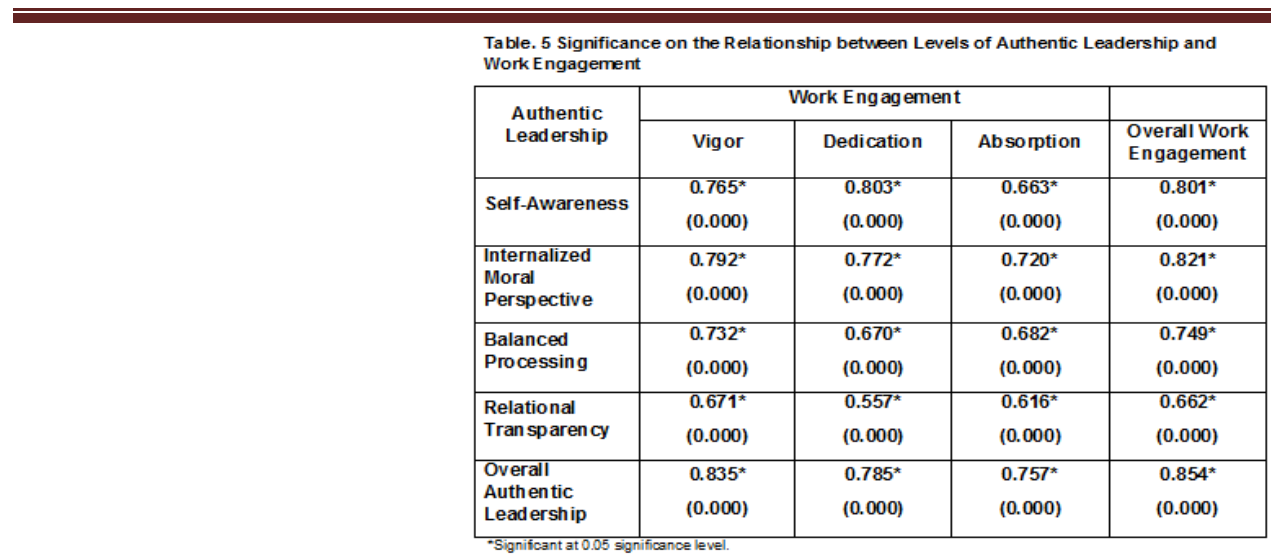

\subsection{Significance on the Relationship between Levels of Teamwork Attitude and Work Engagement}

Displayed in Table 6 were the results of the test of relationship between teamwork attitudes and work engagement. Reflected in the hypothesis, the relationship was tested at 0.05 level of significance. The overall $\mathrm{r}$-value of .822 with a $\mathrm{p}$-value of $<0.01$ signified the rejection of the null hypothesis. It means that there is a significant relationship between teamwork attitude and work engagement. This implies that the school heads' teamwork attitude is correlated with work engagement.

The result of the study linked from Bakker, Emmerik, \&Euwema, (2006) that teamwork attitudes and work participation are linked to the burnout of individual team members in terms of fatigue, frustration and decreased professional effectiveness and work commitment in terms of vigour, determination and absorption after managing the job demands and resources of individual members.

\begin{tabular}{|c|c|c|c|c|}
\hline \multirow{2}{*}{$\begin{array}{l}\text { Tearmwork } \\
\text { Attitudes }\end{array}$} & \multicolumn{3}{|c|}{ Work Engagement } & \multirow[b]{2}{*}{$\begin{array}{l}\text { Overall Work } \\
\text { Engagement }\end{array}$} \\
\hline & Vigor & Dedication & Absorption & \\
\hline Team Structure & $\begin{array}{l}0.717^{*} \\
(0.000)\end{array}$ & $\begin{array}{l}0.713^{*} \\
(0.000)\end{array}$ & $\begin{array}{l}0.636^{*} \\
(0.000)\end{array}$ & $\begin{array}{l}0.742^{*} \\
(0.000)\end{array}$ \\
\hline Lead ership & $\begin{array}{l}0.722^{*} \\
(0.000)\end{array}$ & $\begin{array}{l}0.749^{*} \\
(0.000)\end{array}$ & $\begin{array}{l}0.595^{*} \\
(0.000)\end{array}$ & $\begin{array}{l}0.741^{*} \\
(0.000)\end{array}$ \\
\hline $\begin{array}{l}\text { Situation } \\
\text { Monitoring }\end{array}$ & $\begin{array}{l}0.752^{*} \\
(0.000)\end{array}$ & $\begin{array}{l}0.738^{*} \\
(0.000)\end{array}$ & $\begin{array}{l}0.625^{*} \\
(0.000)\end{array}$ & $\begin{array}{l}0.759^{*} \\
(0.000)\end{array}$ \\
\hline Mutual Support & $\begin{array}{l}0.761^{*} \\
(0.000)\end{array}$ & $\begin{array}{l}0.760^{*} \\
(0.000)\end{array}$ & $\begin{array}{l}0.666^{*} \\
(0.000)\end{array}$ & $\begin{array}{l}0.785^{*} \\
(0.000)\end{array}$ \\
\hline Communication & $\begin{array}{l}0.768^{*} \\
(0.000)\end{array}$ & $\begin{array}{l}0.735^{*} \\
(0.000)\end{array}$ & $\begin{array}{l}0.702^{*} \\
(0.000)\end{array}$ & $\begin{array}{l}0.792^{*} \\
(0.000)\end{array}$ \\
\hline $\begin{array}{l}\text { Overall } \\
\text { Teamwork } \\
\text { Attitudes }\end{array}$ & $\begin{array}{l}0.802^{\star} \\
(0.000)\end{array}$ & $\begin{array}{l}0.796^{\star} \\
(0.000)\end{array}$ & $\begin{array}{l}0.694^{\star} \\
(0.000)\end{array}$ & $\begin{array}{l}0.822^{*} \\
(0.000)\end{array}$ \\
\hline
\end{tabular}

\subsection{Mediating Effect}

Mediation is the accounted variance of MV when regressed together with IV towards DV. The result indicates that the power of the mediating variable, which is 0.5185 , is greater than the 
International Journal of Business Management and Economic Review

Vol. 4, No. 06; 2021

ISSN: 2581-4664

residual value of IV $\left(c^{\prime}\right)=0.3165$, further implying that $\mathrm{WE}$ alone is a stronger predictor of $\mathrm{AL}$ rather than TA.

\begin{tabular}{|c|r|r|r|r|r|}
\hline \multirow{2}{*}{ PATH } & \multicolumn{2}{|c|}{ ESTIMATES } & & & \\
\cline { 2 - 5 } & Unstandardized & Standardized & SE & C.R & P \\
\hline TA $\longrightarrow$ AL & .913 & .873 & .027 & 33.696 & $* * 8$ \\
\hline TA $\longrightarrow$ WE & .316 & .306 & .058 & 5.455 & $* 8 *$ \\
\hline AL $\longrightarrow$ WE & .568 & .576 & .055 & 10.256 & $* * 8 *$ \\
\hline
\end{tabular}

\subsection{Total, Direct and Indirect Effects}

Shown in Table 11 are the values of direct, indirect and total effects of the path analysis conducted. Path analysis was utilized to determine whether Authentic Leadership (AL) significantly mediates the relationship of Teamwork Attitudes (TA) and Work Engagement (WE). In this case, mediation leads to impact transition of Teamwork Attitudes (TA) to Work Engagement (WE) through Authentic Leadership (AL). Multiplying the paths which constitute the effect calculates an indirect effect. The indirect effect magnitude indicates the amount of mediation through the respective mediator variables. In this case, the original value of the direct effect of Teamwork Attitudes (TA) and Work Engagement (WE) significantly reduced to 0.32, the value of the direct effect of Teamwork Attitudes (TA) and Work Engagement (WE) at the entry of Authentic Leadership (AL). This means that the mediated value of 0.52 is the indirect effect of Authentic Leadership (AL) to Work Engagement (WE). In this case, since the direct effect of Teamwork Attitudes (TA) to Work Engagement (WE) remained to be significant despite reduction of its beta, the mediation is considered to be partial. 
International Journal of Business Management and Economic Review

Vol. 4, No. 06; 2021

ISSN: 2581-4664

\begin{tabular}{|c|c|c|c|}
\hline \multirow[b]{2}{*}{ E ffe ct } & \multirow[b]{2}{*}{$b$} & \multicolumn{2}{|c|}{$9536 \mathrm{a}$} \\
\hline & & Lower & Upper \\
\hline $\begin{array}{l}\text { Total } \\
\text { Direct } \\
\text { Indirect (mediation) }\end{array}$ & $\begin{array}{l}.8346 \\
.3161 \\
.5185\end{array}$ & $\begin{array}{l}.7712 \\
.2018 \\
.4056\end{array}$ & $\begin{array}{l}.8981 \\
.4304 \\
.6200\end{array}$ \\
\hline
\end{tabular}

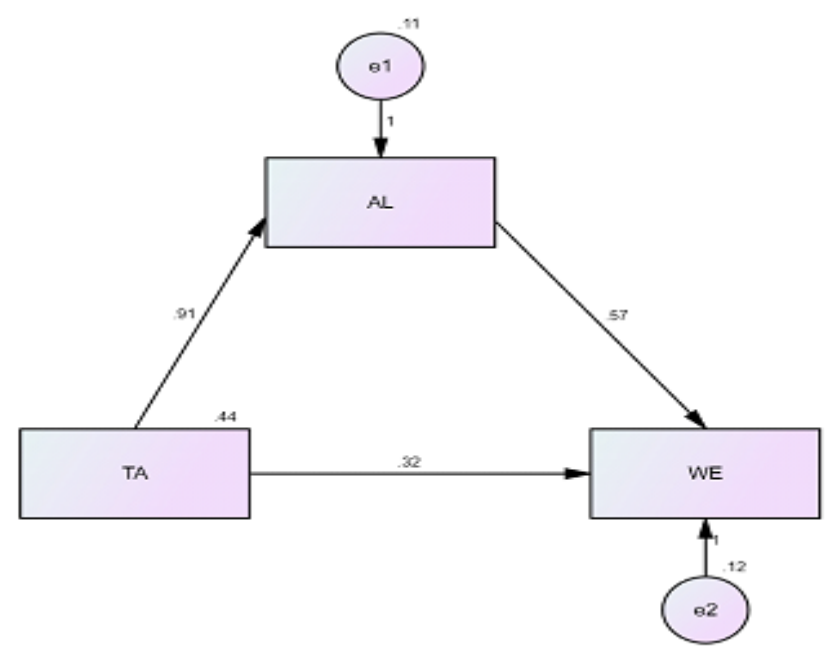

Figure 2. Mediation Analy sis of the Study

Legend: $\quad \begin{aligned} & \mathrm{X}=\text { Teamwork Attitudes } \\ & \mathrm{Y}=\text { Work Engegement }\end{aligned}$

MN= Authentic Leaders hip

\section{REFERENCES}

Aycan, Z. (2006). Paternalism.In Indigenous and cultural psychology (pp. 445466).Springer,Boston, MA. Avolio, B. J., Gardner, W. L., Walumbwa, F. O., $\quad$ Luthans, F., \& May, D. R. (2004). Unlocking the mask: A look at the process by which authentic leaders impact follower attitudes and behaviors. The leadership quarterly, 15(6),801-823.

Avolio, B. J., \& Gardner, W. L. (2005). Authentic leadership development: Getting to the root of positive forms of leadership. The leadership quarterly, 16(3), 315-338.

Baron, R.M. \& Kenny, D.A. (1986). The moderator mediator variable distinction in so cial psychological research: Conceptual, strategic, and statistical considerations. Journal of Personality and Social Psychology, 51(6), 1173- 1182.http://dx.doi.org/10.1037/0022 3514.51.6.1173

Bakker, A. B., Emmerik, H. V., \&Euwema, M. C. (2006).Crossover of burnout and engagement in work teams. Work and occupations, 33(4), 464-489.

Bakker, A. \&Demerouti, E. (2008), "Towards a model of work engagement", Career Development International, Vol. 13 No. 3, pp. 209223. https://doi.org/10.1108/136204308108 0476

Brock, D., Abu-Rish, E., Chiu, C. R., Hammer, D., Wilson, S., Vorvick, L.,\&Zierler, B. (2013). 


\section{International Journal of Business Management and Economic Review}

Vol. 4, No. 06; 2021

ISSN: 2581-4664

Republished:Interprofessional education in team communication: working together to improve patient safety. Postgraduate medical journal, 89(1057), 642-651.

Calderon, C., (2006). Parallel decoupled terminal-edge bisection method for 3D meshgeneration. Engineering with Computers, 22(2), 111-119.

Chen, X., Bishop, J. W., \& Scott, K. D. (2000). Teamwork in China: Where Reality Challenges Theory and Practice 1. In Management and organizations in the Chinese context (pp. 269 282). Palgrave Macmillan, London.

Crossman, A. (2018). What you need to understand about purposive sampling, Retrieved from https://www.thoughtco.com/purposive sampling-3026727

Gehle, T. (2013). Core research designs part 2: Quasi experimental designs. Grand Canyon University College of Doctoral Studies, Grand Canyon University, Phoenix, Arizona.

González-Romá, V., Schaufeli, W. B., Bakker, A. B., \& Lloret, S. (2006). Burnout and work engagement: Independent factors or oppositepoles?. Journal of vocational behavior, 68(1), 65174.

Hassan, A., \& Ahmed, F. (2011).Authentic leadership, trust and work engagement. International Journal of Human and Social Sciences, 6(3), 164-170.

Luthans, F., \&Avolio, B. J. (2009).The "point" of positive organizational behavior. Journal of Organizational Behavior: The International Journal of Industrial, Occupational and Organizational Psychology and Behavior, 30(2), 291-307.

Lyubovnikova, J., Legood, A., Turner, N., \& Mamakouka, A. (2017). How authentic leadership influences team performance: The mediating role of team reflexivity. Journal of business Ethics, 141(1), 59-70.

Michie, S., \&Gooty, J. (2005). Values, emotions, and authenticity: Will the real leader please stand up?. The Leadership Quarterly, 16(3), 441457.

Paler-Calmorin, L., \&Calmorin, M. A. (2007). Research methods and thesis writing. Rex Book Store.

Pennsylvania State University. (2017). Lesson 12: Authentic Leadership. In PSYCH485: Leadership in Work Settings: Spring 2017. Retrieved from: http://psu.instructure.com.

Roozeboom, M.B. \&Schelvis, R. (2016).Book of Proceedings. K. Teoh (Ed.). European Academy of Occupational Health Psychology.

Ruiz Ulloa, B. \& Adams, S. (2004), "Attitude toward teamwork and effective teaming", Team Performance Management, Vol. 10 No. 7/8, pp. 145 151.https://doi.org/10.1108/135275904105 9869

Santos, R. (2007). Methods of research.Quezon City: R.P. Garcia Publishing Company, Inc.

Schaufeli, W. B., \& Bakker, A. B.,(2004) 'Job demands, job resources, and their relationship with burnout and engagement: a multi-sample study', Journal of Organizational Behavior, Volume 25, pp. 293-315

Verma, P. (2015). What is productivity and how is it measured? A new Productivity Commission Staff Research Note unpacks the concept of productivity and how it is measured. Retrievedfromhttps://www.pc.gov.au/news-media/pc news/previous-editions/pc-news-may 2015/productivity-and-how-measured Yukelson, D. (1997). Principles of effective team building interventions in sport: A direct services approach at Penn State 